\title{
Stably Integrated Mouse Mammary Tumor Virus Long Terminal Repeat DNA Requires the Octamer Motifs for Basal Promoter Activity
}

\author{
ELENA BUETTI* \\ Swiss Institute for Experimental Cancer Research, CH-1066 Epalinges, Switzerland \\ Received 27 July 1993/Returned for modification 30 September 1993/Accepted 4 November 1993
}

\begin{abstract}
In the mouse mammary tumor virus promoter, a tandem of octamer motifs, recognized by ubiquitous and tissue-restricted Oct transcription factors, is located upstream of the TATA box and next to a binding site for the transcription factor nuclear factor I (NF-I). Their function was investigated with mutant long terminal repeats under different transfection conditions in mouse Ltk $^{-}$cells and quantitative $\mathrm{S} 1$ nuclease mapping of the transcripts. In stable transfectants, which are most representative of the state of proviral DNA with respect to both number of integrated DNA templates and chromatin organization, a long terminal repeat mutant of both octamer sites showed an average 50-fold reduction of the basal transcription level, while the dexamethasonestimulated level was unafiected. DNase I in vitro footprinting assays with L-cell nuclear protein extracts showed that the mutant DNA was unable to bind octamer factors but had a normal footprint in the NF-I site. I conclude that mouse mammary tumor virus employs the tandem octamer motifs of the viral promoter, recognized by the ubiquitous transcription factor Oct-1, for its basal transcriptional activity and the NF-I binding site, as previously shown, for glucocorticoid-stimulated transcription. A deletion mutant with only one octamer site showed a marked base-level reduction at high copy number but little reduction at low copies of integrated plasmids. The observed transcription levels may depend both on the relative ratio of transcription factors to DNA templates and on the relative affinity of binding sites, as determined by oligonucleotide competition footprinting.
\end{abstract}

Transcriptional control of mouse mammary tumor virus (MMTV) involves protein factors recognizing and binding to specific DNA sequences in the proviral long terminal repeat (LTR). DNA elements mediating positive $(40,57,69,70$, $110)$ or negative $(40,45,57,70,73)$ regulation have been identified by functional assays in tissue culture cells, and elements involved in tissue-specific expression have been defined by analyses of naturally occurring variant LTRs in pathologic situations $(5,29,47,56,66,67,105)$ or by the generation of transgenic mice $(72,90$; reviewed in reference 44). An important class of positively acting factors comprises several types of steroid hormone-receptor complexes: glucocorticoids (13), progestins (18), and androgens (28). The hormone responsive element extends to approximately $200 \mathrm{bp}$ upstream of the transcription start site and has been extensively characterized with respect to the regulation by glucocorticoids $(14,15,21,48,52,61,82)$ and progestins $(17$, 20,41 ). Analysis by linker-scanning (LS) mutagenesis has defined multiple, distinct sequence elements acting cooperatively to achieve maximal glucocorticoid stimulation of the MMTV promoter $(15,16,52)$. Two of them are located in DNA segments shown to bind in vitro the purified glucocorticoid receptor: the strongest, distal element (around position -175) cooperates with a weaker proximal one, which in turn requires a nuclear factor I (NF-I) binding site centered around position $-70(2,12,15,16,19,68,106)$. In vivo, NF-I binding was observed in conjunction with alterations of the chromatin structure brought about by hormone treatment $(3$, 27, 81).

In vitro footprinting studies with nuclear protein extracts of mouse tissues showed a protection against DNase I

\footnotetext{
* Phone: (41 21) 3165916 or 31659 36. Fax: (41 21) 6526933.
}

digestion of further sequences $(-62$ to -37$)$ next to the NF-I binding site that are related to the octamer/NF-III recognition motifs and present as a 10-bp direct repeat (65). A similar configuration of adjacent NF-I and NF-III sites is found in the DNA of adenovirus type 2, in which both sites are required for viral DNA replication (84-86). Octamerrelated sequences occur in transcriptional regulatory elements of several genes, including the promoters of histone H2B (100) and of immunoglobulin light- and heavy-chain genes $(30,79)$ and the enhancers of immunoglobulin heavy chain $(6,37)$, U1 and U2 small nuclear RNAs $(25,51,63)$, and simian virus 40 (SV40) $(74,109)$.

Octamer sequences are recognized by a family of transcription factors that can be either ubiquitous or specific for certain cell types (reviewed in references 50 and 91 ). The factor called Oct-1 (or OTF-1, NF-A1, OBP100, or NF-III) has been found in every cell type analyzed so far $(9,33,88$, 99,104 ), whereas Oct-2 (or OTF-2 or NF-A2) is present preferentially in B lymphocytes, in which it is involved in the control of immunoglobulin gene transcription $(35,54,96$, 102). Other members of the octamer family of transcription factors were found in selected cell types of mouse embryonal origin $(78,97)$ or in rat brain tissue $(46)$.

A functional role for the octamer-related sequences in the MMTV promoter was first defined by Toohey et al. (106) by using transient-transfection assays in mouse Ltk $^{-}$cells, in which mutation of the sequences between -59 and -38 led to a decrease in transcriptional activity of 10 -fold or more compared with that in the wild type, both in the presence and in the absence of glucocorticoids. However, another mutational analysis showed a fourfold reduction in hormonestimulated activity in HeLa cells transiently cotransfected with plasmids expressing the glucocorticoid receptor and no effect on basal transcription determined in a cell-free assay 
(11). Purified Oct-1 factor from HeLa cells was shown to bind to the octamer sequences of the MMTV promoter in DNase I footprinting experiments (11).

In this study, I investigated the role of the MMTV octamer motifs by using mutated LTRs under different transfection conditions, in particular stable transfection, which is more representative of the state of proviral DNA in virus-infected cells. In parallel, in vitro footprinting experiments were performed to analyze the interactions of the wild-type and mutated MMTV promoter region with nuclear protein extracts containing the endogenous factors. The results show that the main function of the octamer sequence was to control the basal promoter activity, whereas it only marginally affected glucocorticoid-induced levels. Relative amounts of template and factors also played an important role in determining the final transcription level. This notion was corroborated by the footprinting results which suggested cooperation of factors bound to the NF-I and octamer sites in a manner that was also dependent on the relative factor concentrations and the nature of the sequences in the recognition sites.

\section{MATERIALS AND METHODS}

Plasmid construction. Construction of the LS wild type and mutants has been described previously (52). LS -66/ -45 was newly constructed and was further used for the generation of the oct mutant altered in both octamer sites. For this, the preliminary elimination of an unexpected BstEII site in the pBR 322 portion (near the PvuII site) was carried out as follows. LS $-66 /-45$ was digested to completion with $P v u I I$ and partially with $B s t$ EII; nearly full-length linear molecules were isolated by agarose gel electrophoresis, made flush with Klenow DNA polymerase and deoxynucleotides, self-ligated, digested with $P v u I I$, and used for transformation of competent Escherichia coli DH5 bacteria. A plasmid with only the BstEII site in the MMTV LTR (positions +105 to +111 ) was isolated and amplified. The mutation of both octamer sites was first introduced in a DNA fragment by PCR with 0.1 pmol of template LS $-66 /-45$ and 20 pmol each of the following deoxyoligonucleotide primers: a 48-mer with the coding-strand sequence of the oct mutant (Fig. 1B) between -65 and -18 , and a 21 -mer with the non-coding-strand sequence between +130 and +110 . The reaction mixture $(0.1 \mathrm{ml})$ was $20 \mathrm{mM}$ Tris $\cdot \mathrm{HCl}(\mathrm{pH} 8.5), 1.5$ $\mathrm{mM} \mathrm{MgCl}, 25 \mathrm{mM} \mathrm{KCl}, 0.1 \mathrm{mg}$ of gelatin per ml, and 0.05 mM (each) dATP, dGTP, dTTP, and dCTP. The PCR was carried out with $1 \mathrm{U}$ of Amplitaq (Perkin-Elmer Cetus) for 20 cycles at an annealing temperature of $55^{\circ} \mathrm{C}$, and the product was purified by extraction with phenol-chloroform and ethanol precipitation and then digested with HindIII and BstEII. The resulting fragment of approximately 175 bp was purified by agarose gel electrophoresis and ligated to the gel-purified, 5-kb HindIII-BstEII fragment of the LS -66/ -45 plasmid. After transformation of $E$. coli DH5 bacteria, colonies were screened for the presence of plasmids containing the XhoI site that replaced the distal octamer site (Fig. 1B). Large-scale preparations of plasmids, propagated in $E$. coli DH5, were purified by the polyethylene glycol precipitation method (92), and their concentrations were verified by ethidium bromide staining of agarose gels. The promoter regions of both mutants were sequenced by the chain termination method (93) on supercoiled templates (22). All restriction and modification enzymes were used by following the recommendations of the supplier (Boehringer Mannheim). Standard molecular biology techniques were applied according to established protocols (92).
DNase I footprinting. Nuclear extracts were prepared from Ltk ${ }^{-}$cells (treated for $15 \mathrm{~h}$ with $10^{-7} \mathrm{M}$ dexamethasone) by following the method of Shapiro et al. (98) until the precipitation with ammonium sulfate. The following inhibitors were added immediately before use: aprotinin (1\%), phenylmethylsulfonyl fluoride $(0.5 \mathrm{mM}$ to the hypotonic and sucrose restore buffers and $0.1 \mathrm{mM}$ to the resuspension buffer), benzamidine $(2.5 \mathrm{mM})$, and $\mathrm{NaF}(5 \mathrm{mM})$. The resuspension, dialysis, and determination of protein concentration by optical density were performed by the method of Gorski et al. (39). A total of 40 petri dishes (15- $\mathrm{cm}$ diameter; approximately $10^{9}$ cells) yielded $10 \mathrm{mg}$ of nuclear proteins. Extracts, at a final concentration of about $5 \mathrm{mg} / \mathrm{ml}$, were stored in small aliquots in liquid nitrogen. DNase I footprinting assays were performed by following modifications $(58,65)$ of the original method (34), essentially as previously described (65). Asymmetrically radiolabeled DNA probes were prepared by incubation of plasmids with BamHI (Fig. 1A), calf intestinal phosphatase, and then $\left[\gamma-{ }^{32} \mathrm{P}\right] \mathrm{ATP}$ and polynucleotide kinase and subsequent digestion with $S t y \mathrm{I}$. The $0.45-\mathrm{kb}$ fragment from the StyI $(-303)$ to the BamHI $(+142)$ sites was isolated by electrophoresis on a nondenaturing $5 \%$ polyacrylamide gel and electrophoretically eluted (Biotrap; Schleicher and Schuell). An aliquot was used for the purine sequencing reaction by the method of Maxam and Gilbert (64). Labeled fragments (10 fmol) plus $1 \mu \mathrm{g}$ of doublestranded poly(dI-dC) competitor DNA were incubated with 50 to $60 \mu \mathrm{g}$ of nuclear protein extract in $20-\mu \mathrm{l}$ binding reaction mixtures for $30 \mathrm{~min}$ at $0^{\circ} \mathrm{C}$ in a buffer (65) supplemented with $5 \mathrm{mM} \mathrm{NaF}$ and digested (65) with DNase I (Worthington) for $5 \mathrm{~min}$ at $0^{\circ} \mathrm{C}$. Samples without nuclear extract received a 20-fold dilution of DNase for 2 or $5 \mathrm{~min}$. In competition experiments, the indicated amount of doublestranded oligonucleotides in $1 \mu \mathrm{l}$ was added to the binding reaction mixture $10 \mathrm{~min}$ prior to the addition of the labeled DNA. The competitor oligonucleotides (65) have the following sequences: MMTV LTR wild type, from -84 to -58 for NF-I, and from -62 to -39 for oct; adenovirus type 2 major late promoter, from -41 to -2 for the unspecific (U) competitor (Fig. 1C). The reactions were stopped with a buffer containing sodium dodecyl sulfate and proteinase $\mathbf{K}$ and incubated at $40^{\circ} \mathrm{C}$ for $1 \mathrm{~h}$, and nucleic acids were extracted and precipitated in the presence of carrier tRNA (65). Samples were separated by electrophoresis on 5\% denaturing polyacrylamide gels (64) that were fixed and dried prior to autoradiography at $-70^{\circ} \mathrm{C}$ with Dupont-Cronex intensifying screens.

Cell culture and transfection. Mouse $\mathrm{Ltk}^{-}$cells were cultured in Dulbecco's modified Eagle's medium with $10 \%$ fetal calf serum and antibiotics. Transient transfections were carried out by the DEAE-dextran method (60) with $5 \mu \mathrm{g}$ of MMTV plasmid and $1 \mu \mathrm{g}$ of plasmid H514, containing the rabbit $\beta$-globin gene and SV40 enhancer sequences (7). The cultures, in 10-cm petri dishes, were incubated with DNA for $8 \mathrm{~h}$, subjected to a $10 \%$ dimethyl sulfoxide shock $(60)$ for 2 min at room temperature, washed, and incubated with complete medium for a further $65 \mathrm{~h}$. Dexamethasone (Sigma) was added to a final concentration of $5 \times 10^{-7} \mathrm{M} 17 \mathrm{~h}$ before RNA extraction. Stable transfections were performed by the calcium phosphate method (42) with $5 \mu \mathrm{g}$ of the MMTV plasmids per 6-cm dish as previously described (52). Thymidine kinase (TK)-positive clones were selected with hypoxanthine-aminopterin-thymidine (HAT) medium (59). For hygromycin B selection, $1.5 \mu \mathrm{g}$ of a plasmid containing the hygromycin B resistance gene (8) under the control of the SV40 promoter was coprecipitated onto the cells. These 
were split 1:3 after $24 \mathrm{~h}$, and selection was started 1 day later with medium containing $200 \mu \mathrm{g}$ of hygromycin B per ml. In both selections, pools of resistant clones from each independent transfection were expanded for RNA and DNA analysis.

Nucleic acid isolation and S1 mapping. DNA and cytoplasmic RNA were extracted from stably transfected cells as previously described (14). DNA blot analysis was performed by the method of Southern $(92,101)$ with an LTR probe labeled with ${ }^{32} \mathrm{P}$ by using random oligonucleotide primers (32). Total cellular RNA was extracted from transiently transfected cells by the guanidinium thiocyanate method (24), digested with RNase-free DNase I, extracted with phenol-chloroform, and reprecipitated with ethanol. For the S1 nuclease mapping experiments $(31)$, the following $5^{\prime}-{ }^{32} \mathrm{P}$ labeled DNA fragments were prepared: for the analysis of MMTV transcripts, the EcoRI-BamHI fragment of the plasmid $\mathrm{p} \Delta 47 \mathrm{~B}$ (52) extending from -204 to +142 ; for the $\beta$-globin internal standard, the $2.5-\mathrm{kb} B a m \mathrm{HI}$ fragment of pH514 (52); for the $\beta$-actin control, a 425-bp BglII-PvuII fragment from a SP64 plasmid with the coding portion of the mouse $\beta$-actin gene (71) inserted as a PstI fragment. To obtain a signal of comparable intensity, the specific activity of the $\beta$-actin probe was reduced by adding a 50 -fold molar excess of an unlabeled, linearized plasmid. RNA ( 25 or 50 $\mu \mathrm{g})$ was hybridized to 5 or $10 \mathrm{fmol}$ of 5'-end-labeled MMTV or $\beta$-globin probe and $200 \mathrm{fmol}$ of $\beta$-actin probe in $20 \mu \mathrm{l}$ at $52^{\circ} \mathrm{C}$ for 5 to $16 \mathrm{~h}$ and digested with $1,300 \mathrm{U}$ of $\mathrm{S} 1$ nuclease (Sigma) per $\mathrm{ml}$ for $30 \mathrm{~min}$ at $32^{\circ} \mathrm{C}$. The protected fragments were separated on denaturing $6 \%$ polyacrylamide gels (64) and subjected to autoradiography with intensifying screens. The intensity of the bands was measured by densitometric scanning of films after various exposure times.

\section{RESULTS}

Construction of MMTV LTRs mutated in the promoter region. For the functional analysis of the MMTV promoter, mutations were introduced in an almost complete MMTV LTR (from the PstI site 8 bp into the LTR sequence to the $P v u I I$ site at its $3^{\prime}$ end) linked to the coding region of the TK gene of herpes simplex virus (Fig. 1A). The wild-type plasmid (pLSwt) and the generation of LS mutants, by ligation of a $3^{\prime}$-deleted and a $5^{\prime}$-deleted moiety via a synthetic linker containing a HindIII restriction site, have been described (52). For the present study, the target sequence for mutagenesis was a 10 -bp direct repeat located immediately upstream of the TATA box (Fig. 1B) that contains consensus octamer motifs able to bind in vitro the ubiquitous transcription factor Oct-1 (11). To rigorously test the role of the octamer sites, they were both mutated without altering relative distances in the DNA. The oct mutant (Fig. 1B) was produced by PCR with an oligonucleotide carrying a HindIII site (for ligation into pLS $-66 /-45$ ) and a XhoI site (for selection) replacing the distal octamer site, the proximal site being mutated by transversions. The sequence alterations involve the positions -61 to -39 from the transcription start site and were verified by sequencing. The construct is otherwise identical to pLSwt, with a minor sequence difference in the plasmid portion of both mutants due to the suppression of an unexpected BstEII site. Another mutant, LS $-66 /-45$, has a 12-bp deletion, including the distal octamer motif, whereas the adjacent palindromic recognition sequence for NF-I is reconstituted by the HindIII linker. Therefore, it contains only one copy of the octamer motif, with unchanged distances to the NF-I site and the TATA box, and is shorter by approximately one turn of the DNA helix (Fig. 1B).

Binding of nuclear proteins to wild-type and mutant promoters. As a preliminary test, we investigated the ability of the mutants, in comparison to wild-type LTR, to bind nuclear proteins from mouse $\mathrm{Ltk}^{-}$cells. These are the cells chosen for functional assays, as they are permissive for the function of the MMTV promoter and for a strong transcriptional stimulation by glucocorticoid hormones $(13-15,106)$. End-labeled DNA fragments spanning the promoter region were incubated with nuclear extracts of dexamethasonetreated $\mathrm{Ltk}^{-}$cells and subjected to mild digestion with DNase I in a footprinting experiment (Fig. 2). The pattern of protection of wild-type DNA in the basal promoter region shows a continuous footprint from -82 to -24 that includes the recognition sequences of NF-I and Oct-1/NF-III, plus the TATA box. A second footprint extending from -8 to +20 includes the RNA start site. Finally, at least two distinct protected areas are visible in the distal region upstream of -170 , one of them containing the glucocorticoid receptor binding site. Although on the opposite DNA strand and with a different resolution, the wild-type pattern follows closely the one described previously for Ltk $^{-}$cells (65). In contrast, DNA mutated in both octamer sites between positions -38 and -62 (Fig. 2, OCT mut) showed, as predicted, a loss of protection in the octamer region, while maintaining a clear NF-I footprint next to it. The TATA box area showed an altered pattern, interrupted by a new hypersensitive site at -31 . No changes were detectable in the footprint spanning the cap site or in those of the distal region. DNA of the LS $-66 /-45$ mutant is clearly protected in the NF-I region. Further downstream, it shows a footprint corresponding to the single octamer site between -35 and -45 and a weak one corresponding to the TATA box, without interruptions by hypersensitive sites. These are present at the outer edges of the promoter region (at -23 and -85 ) as in wild-type DNA. Again, no alterations were observed in the other protected sites downstream or upstream. These data show that in vitro, the mutant LTR DNAs have the predicted properties of binding nuclear factors.

Transcriptional activity of promoters mutated in the octamer motifs. The functional effect of the octamer mutation was first tested in transient-expression assays with Ltk $^{-}$ cells that were treated with $5 \times 10^{-7} \mathrm{M}$ dexamethasone, a synthetic glucocorticoid, for $17 \mathrm{~h}$ before RNA extraction. The MMTV plasmids were cotransfected with a reference plasmid containing the rabbit $\beta$-globin gene under the control of the SV40 enhancer (7). Correctly initiated, stable mRNAs were detected in nuclease $\mathrm{S} 1$ protection experiments with 5 '-end-labeled DNA probes that span the RNA initiation site for MMTV and the beginning of the second exon for the globin gene (62). After being annealed with RNA, labeled fragments of 142 nucleotides (nt) for MMTV and $212 \mathrm{nt}$ for globin were protected from S1 digestion, and the intensity of these bands was quantitated by densitometry of the autoradiographs. Figure 3 shows the results of independent transfection assays with the mutant of both octamer sites and the wild-type plasmid for comparison. The average of the ratios of the intensity of the MMTV-specific band to that of the reference globin band was $2.09( \pm 0.21)$ for the wild type and $1.47( \pm 0.20)$ for the octamer mutant, which therefore displayed an average transcriptional activity of about $70 \%$ of that of the wild type (between 55 and $89 \%$, considering the extremes of the standard deviation). This result shows that in transient assays, the mutation in the octamer sites did not 
A

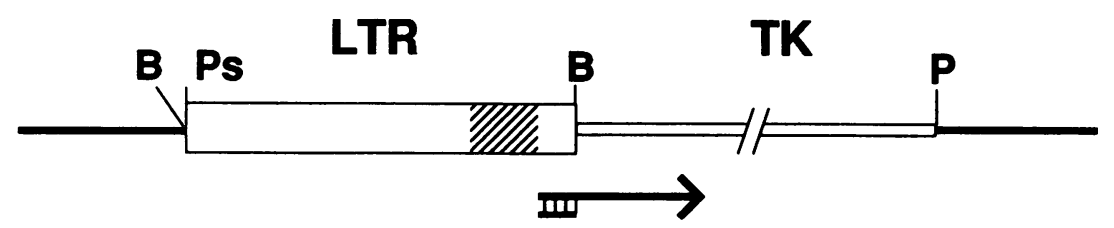

B

wT

$\begin{array}{lccc}-90 & -70 & -50 & -30 \\ \text { TTCCTATGTTCTTTTGGAATCTATCCAAGTCTTATGTAAATGCTTATGTAAACCATAATATAAAAGAGTGC } & \stackrel{\text { NF-1 }}{\underline{\text { OCT }}} & \text { OCT } & \text { TATA BOX }\end{array}$

OCT MUT. TTCCTATGTTCTTITGGAATCTATCCAAGCETgCTCgAgCTGCTgCgt gCcCCCATAATATAAAAGAGTGC

LS $_{-12}$ 66/45 TTCCTATGTTCTTTTGGATCTATCCAAG-CTP--G-....--ATGTAAACCATAATATAAAAGAGTGC

LS 11 90/70 T--CaA-G--CTT--G----CTATCCAAGTCTTATGTAAATGCTTATGTAAACCATAATATAAAAGAGTGC

C

5 ' GTTCTTTTGGAATCTATCCAAGTCTT 3'

3 ' CAAGAAAACCTTAGATAGGTTCAGAA 5

5 ' GTCTTATGTAAATGCTTATGTAAA 3 '

3 'CAGAATACATTTACGAATACATTT 5 '

NF-I

5 ' GAAGGGGGCTATAAAAGGGGTGGGGCGCGTTCGTCC 3'

$3^{\prime}$ ' $T$ TCCCCCCGATATTTTCCCCCACCCCCGCGCAAGCAGG 5 '

OCT

FIG. 1. (A) Wild-type plasmid (52). The LTR of MMTV (GR strain) from the PstI to the PvuII sites is linked via a BamHI linker to the herpes simplex virus TK coding region (BglII-PvuII fragment). The hormone regulatory element (shaded area) extends to about $200 \mathrm{bp}$ upstream of the transcription start site (14). The arrow denotes the RNA, and the line below it denotes the protected 142-nt fragment in S1 mapping experiments. Restriction enzyme sites are as follows: B, BamHI; Ps, PstI; and P, PvuII. (B) Sequences of wild-type and mutated promoters. For the NF-I site, the arms of the palindrome and the center at -70 are underlined. The octamer-related motifs are doubly underlined; seven of eight bases are repeated and were considered for mutation. Wild-type sequences are in capital letters, and mutated ones are in lowercase letters; deleted bases are indicated by hyphens, located arbitrarily to maximize the number of matches. Relevant restriction enzyme sites are in boldface letters: HindIII (AAGCTT) of LS mutants and XhoI (CTCGAG) for selection of the PCR-generated oct mutant. (C) Sequence of the double-stranded oligonucleotides used in competition footprinting experiments.

produce a major effect on the level of glucocorticoid-stimulated RNA.

The position of the octamer sequences in front of the TATA box may suggest that they play a role in the basal activity of the MMTV promoter. In view of apparently conflicting data in recent reports $(11,106)$, I decided to examine this possibility with the mutants. As the sensitivity of transient-transfection assays does not allow the detection of unstimulated levels of RNA, I carried out stable transfection experiments with Ltk $^{-}$cells with the octamer mutant, the single-site deletion mutant LS $-66 /-45$, or the wild-type plasmid. Stable transfection has the advantage of reflecting more closely the situation of proviral DNA in infected cells. Two selection procedures were applied for the isolation of transfectants: cotransfection with a plasmid conferring resistance to the antibiotic hygromycin B (8) or selection for $\mathrm{TK}^{+}$cells in HAT medium (59). Independent pools of transfected cells were expanded in selective medium, and parallel cultures were grown in the presence or absence of dexamethasone for $17 \mathrm{~h}$ prior to RNA extraction. S1 nuclease protection assays were performed, and dilutions of the dexamethasone-stimulated samples were loaded on a sequencing gel next to the undiluted corresponding control samples.

From the autoradiographs shown in Fig. 4, two points are immediately obvious: (i) there is no major difference between signals due to dexamethasone-stimulated RNA in mutants and the wild type (Fig. 4A, lanes a and b, and Fig. $4 \mathrm{~B}$, lanes $\mathrm{a}, \mathrm{b}$, and $\mathrm{c}$ ), and (ii) a strong reduction of the unstimulated RNA levels is apparent in the oct mutant transfectants, particularly in the hygromycin B-selected ones (Fig. 4A, lanes c of pools 5 to 8). Densitometry of the autoradiographs and standardization according to the controls (see legend to Fig. 4) yielded the data in Fig. 5. Histograms represent absolute values in arbitrary units that allow a direct comparison between mutants and the wild type within each panel. Induction factors cannot be derived directly; for the wild type, they were in the range of 60 to 160 in hygromycin-selected transfectants and 10 to 50 in $\mathrm{TK}^{+}$ ones. The quantitative data confirmed that the effect of the double octamer mutation was on the basal level of transcrip- 


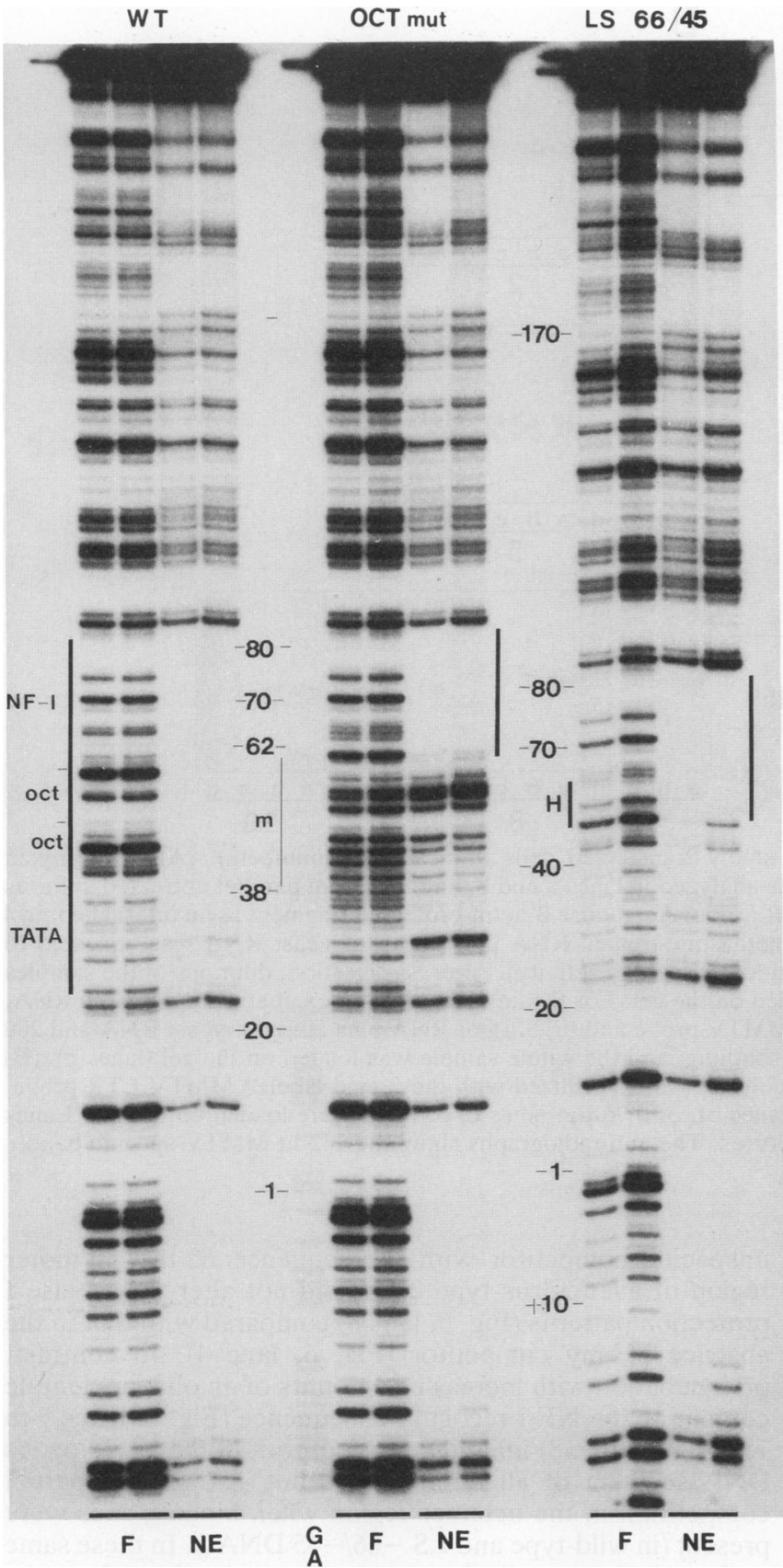

FIG. 2. DNase I footprinting analysis with L-cell nuclear extracts and wild-type DNA (WT), DNA mutated in both octamer motifs (OCT mut), or DNA with only one octamer site (LS 66/45). DNA fragments $5^{\prime}$ end labeled at position +142 and extending to -303 were incubated in the absence (lanes F, free DNA) or in the presence (lanes NE) of nuclear extracts. GA, purine sequence of the fragment. Thick vertical lines indicate the composite footprint in the wild-type probe and the NF-I protected areas in the mutated DNAs. In the LS $-66 /-45$ sequence, the site of the HindIII linker is marked by $H$. In the octamer mutant, the extent of the mutated sequence (m) is marked by a thin line.

tion (Fig. 5A and $\mathrm{C}$ ) and not on the dexamethasone-stimulated one (Fig. 5B and D).

A peculiar, intermediate behavior was observed for the single-octamer site mutant LS $-66 /-45$ with respect to the

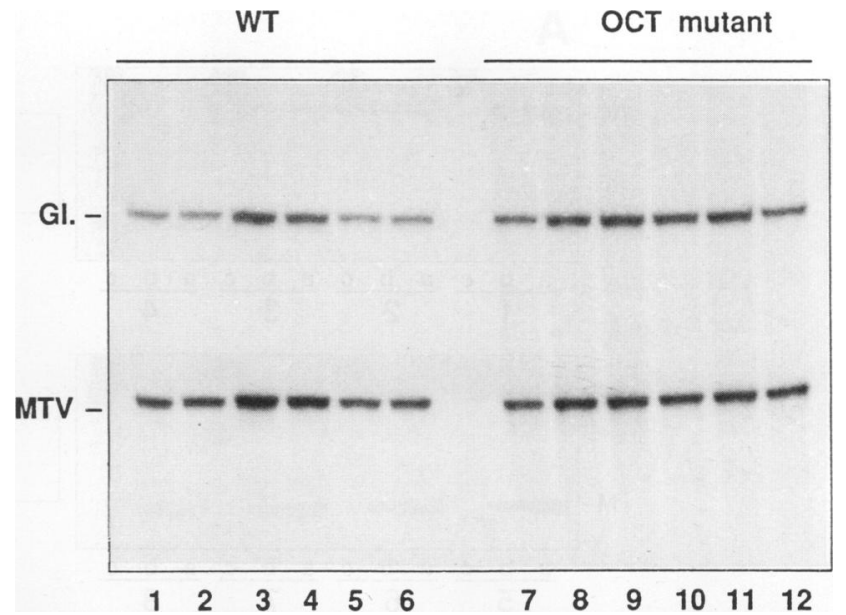

FIG. 3. Transient-expression assays of wild-type and octamermutated DNA analyzed by S1 nuclease protection experiments. Each lane contains the reaction product of an independent cotransfection of an MMTV plasmid with the rabbit $\beta$-globin internal standard plasmid pH514. The cultures were treated with dexamethasone for $17 \mathrm{~h}$ before RNA extraction. The autoradiograph of the denaturing gel displays the 5 '-end-labeled protected fragments corresponding to the MMTV LTR probe (MTV, $142 \mathrm{nt}$ ) and the globin probe (Gl., $212 \mathrm{nt}$ ).

basal levels: as the wild type in hygromycin-selected transfectants (Fig. 5A) and as an octamer mutant in $\mathrm{TK}^{+}$transfectants (Fig. 5C). For the interpretation of the results, it was important to know the number of templates present in the different transfectants. Therefore, in Fig. 5, the approximate copy numbers of integrated plasmids, as determined by Southern transfer analysis of the DNA of each transfected pool, are indicated. Not unexpectedly, on the basis of the experimental setup, this control underlined a major difference between the two types of transfectants: those obtained via independent selection for antibiotic resistance contained grossly comparable numbers (4 to 20 ) of plasmids. When calculated per template unit compared with the wild type, the average basal RNA levels were reduced about 50 -fold in the octamer mutant transfectants and about 2-fold in the single-octamer site LS $-66 /-45$ transfectants. On the contrary, those obtained through TK selection had copy numbers that were low for the wild-type plasmid and 10- to 100 -fold higher for both mutants. In this situation, the selective pressure was exerted on the TK gene product under the control of the (nonstimulated) MMTV promoter itself, and a minimal level of TK protein was required for cell survival in HAT medium. Because the unstimulated MMTV promoter is relatively weak, this experimental setup was used previously to select for multiple-copy transfectants with a detectable basal level of RNA $(13,15)$. The finding of elevated mutant plasmid levels in the transfectants suggests that a selection for fortuitously high-copy-number clones had occurred or that the transfected DNA had undergone an amplification to compensate for the lower transcriptional efficiency of the mutated promoters. Yet the cumulative basal RNA levels remained about 10 -fold lower in the mutants than in the wild type, resulting in a total reduction factor per DNA copy in the order of 100 -fold. In summary, the results show that dexamethasone-induced RNA levels were not reduced to a large extent by either octamer mutation, whereas the basal level was severely lowered by 

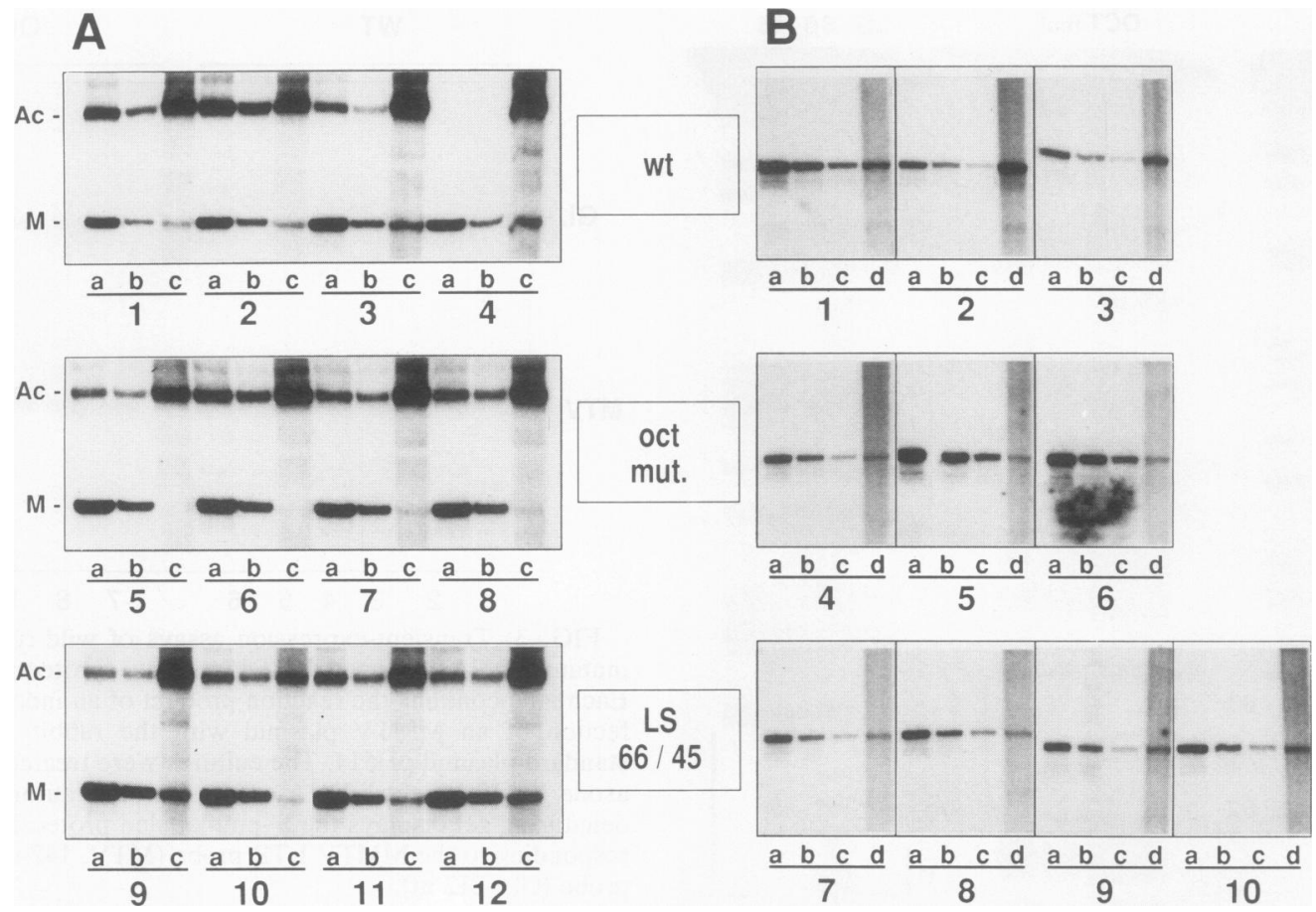

FIG. 4. S1 mapping analysis of RNA from independent pools of stably transfected cells (indicated by numbers). (A) Hygromycin B-selected transfectants. RNA from dexamethasone-treated cultures was analyzed in lanes a and $b$, and that from parallel untreated cultures was analyzed in lanes c. M, 142-nt protected fragment of the MMTV LTR probe; Ac, mouse $\beta$-actin-protected fragment as an internal control (this probe was missing in lanes $4 \mathrm{a}$ and $4 \mathrm{~b}$ ). A total of $5 \mu \mathrm{g}$ of dexamethasone-treated RNA plus $20 \mu \mathrm{g}$ of yeast RNA was annealed to 5 -end-labeled probes for MMTV (10 fmol) and $\beta$-actin ( $200 \mathrm{fmol} ; 50$-fold-lower specific activity). After S1 digestion, dilutions of the samples corresponding to $0.75 \mu \mathrm{g}$ (lanes a) and $3 \mu \mathrm{g}$ (lanes b) of RNA were loaded on the gel. For the analysis of non-dexamethasone-treated RNA, two annealing reaction mixtures with (i) $50 \mu \mathrm{g}$ of RNA and $10 \mathrm{fmol}$ of MMTV probe and (ii) $5 \mu \mathrm{g}$ of RNA plus $20 \mu \mathrm{g}$ of yeast RNA and 200 fmol of $\beta$-actin probe were mixed for the S1 digestion and subsequent handling, and the whole sample was loaded on the gel (lanes c). (B) HAT-selected, Ltk ${ }^{+}$transfectants. RNA from dexamethasone-treated cultures was hybridized with the $5^{\prime}$-end-labeled MMTV LTR probe, and dilutions of the final samples equivalent to $3 \mu \mathrm{g}$ (lanes a), $1.5 \mu \mathrm{g}$ (lanes b), or $0.75 \mu \mathrm{g}$ (lanes c) of RNA were loaded on the gel. Lanes d, products of reactions with $50 \mu \mathrm{g}$ of RNA from parallel untreated cultures. The autoradiographs show the 142-nt MMTV-specific band.

the complete octamer mutation both at high and at moderate copy numbers. The deletion mutant of only one octamer site showed an intermediate result, in that the base level was reduced only at high copy numbers (the state of the integrated DNA templates may play a role in this particular case [see Discussion]).

In vitro interactions of promoter-bound nuclear proteins. Purified NF-I, Oct-1/NF-III, and glucocorticoid or progesterone receptor have been shown to bind individually to their cognate sites on the MMTV DNA in the promoter/upstream region $(11,12,20,76,95)$. When present together, purified Oct-1 and glucocorticoid or progesterone receptor displayed synergistic binding to their respective sites (11). However, this type of study does not take into consideration the relative abundance of factors in the nucleus and their affinities for DNA in the presence of the other nuclear proteins. When crude nuclear extracts were used in footprinting experiments, the binding pattern reflected more accurately the relative functional strength of glucocorticoid regulatory elements (65). Because of the proximity of the recognition sequences for Oct-1 and NF-I in the MMTV DNA, and in view of previous results implicating the NF-I site in the basal level of MMTV RNA synthesis (16), we analyzed the specificity of the protein-DNA interactions in competition assays with double-stranded oligonucleotides and the wild-type or the mutant labeled probes incubated with $\mathrm{Ltk}^{-}$nuclear extracts (Fig. 6). As a control, a high molar excess of an unspecific competitor with the sequence of the promoter region of adenovirus type $2(94)$ did not alter the DNase I protection patterns (Fig. 6, lane 8) compared with that in the absence of any competitor (Fig. 6, lane 4). In contrast, preincubation with increasing amounts of an oligonucleotide containing the NF-I recognition sequence (Fig. 6, lanes 5 to $7, \mathrm{bp}-83$ to -58 ) inhibited the footprint in the homologous DNA segment of all three probes but also gave a partial competition in the octamer region when binding sites were present (in wild-type and LS -66/-45 DNAs). In these same probes, however, displacement of proteins bound to the octamer sites by an oligonucleotide with the homologous sequence (Fig. 6, lanes 9 to 11 , bp -62 to -37 ) did not alter binding to the adjacent NF-I site. Addition of the octamer oligonucleotide also displaced proteins bound to the transcription initiation area $(+1$ to +5$)$. As this effect was also observed in the octamer-mutated DNA and was therefore not dependent on the presence of octamer-bound factors in their cognate sites, it could not be due to interaction of DNA-bound proteins in the octamer and cap sites. Competition was also seen in the distal region, affecting a footprint between approximately -175 and -185 and another one around -215 to -220 . While the latter is still uncharacterized, the one at -175 to -185 is likely to be due to the endogenous glucocorticoid receptor, as the nuclear extracts were prepared from dexamethasone-treated Ltk $^{-}$cells. The identity of a similar footprint observed with mouse liver 

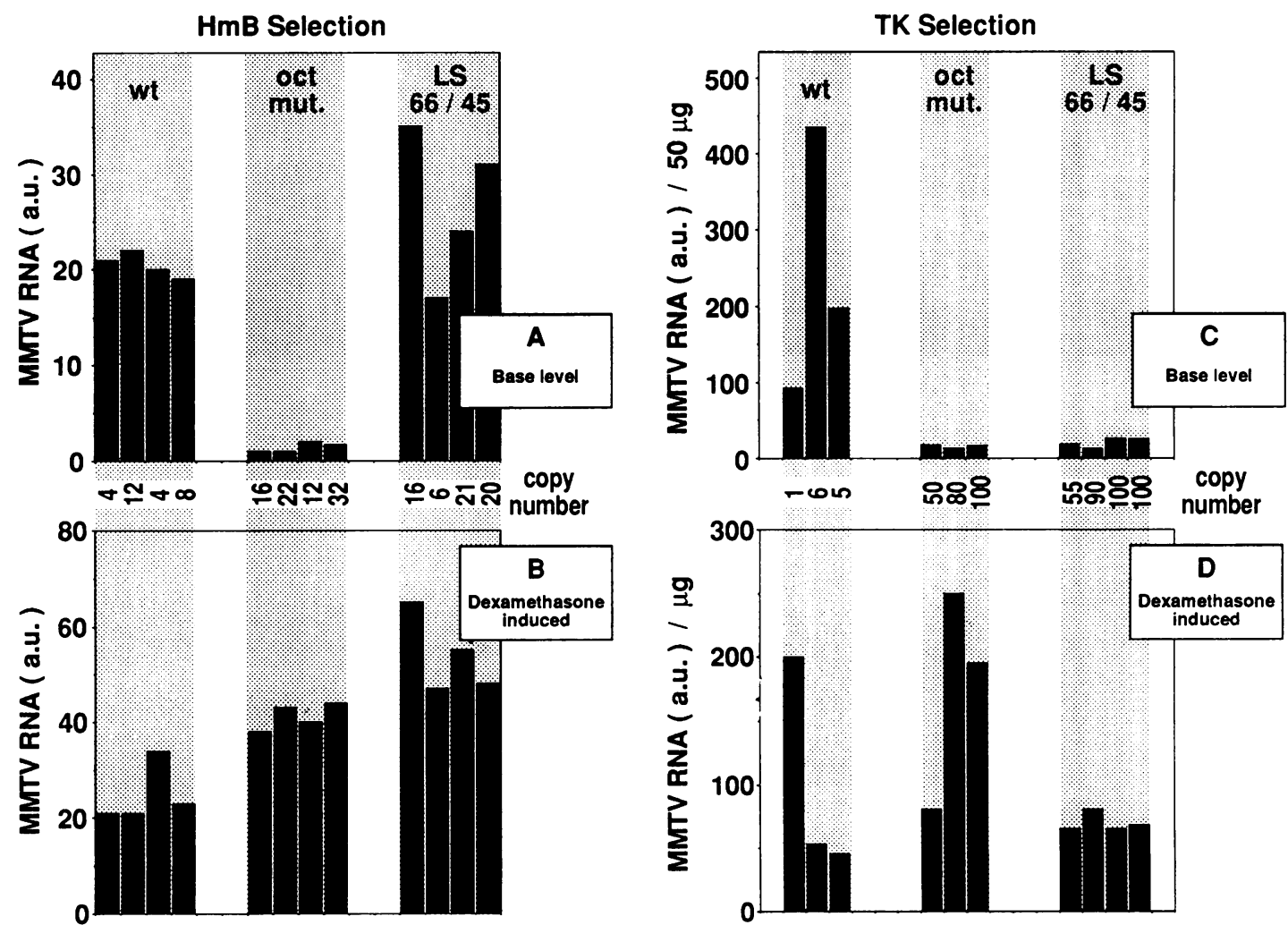

FIG. 5. Quantitation of MMTV-specific transcription in stably transfected cells. The S1 mapping results of the experiments shown in Fig. 4 were analyzed by densitometry of films in the linear range of intensities for the bands of interest. The data were standardized according to the actin internal control (A and B), to the background of the lanes (C), or to the range of dilutions (D) and are expressed in arbitrary units (a.u.). The values can be compared only within each panel. The approximate number of copies of integrated MMTV plasmids was estimated from the intensity of transfected LTR bands in Southern hybridization analyses, by using the mouse endogenous MMTV bands as standards.

extracts has been previously established by using competition with mutated oligonucleotides and with a specific antibody (65). A similar cross-competition pattern by the octamer region oligonucleotide has been described by the same authors (65).

The competition experiments described above (Fig. 6) showed that factors did bind to the NF-I recognition sequence independently from the occupancy of the adjacent octamer sites or from the removal of octamer-binding proteins in the extract, whereas the binding of factors to the octamer sites did require, at least partially, the presence of NF-I on its site. In a previous study (16) we had analyzed a mutant of the NF-I site, LS $-90 /-70$, that retains only the proximal half of the palindrome and is shorter by one helix turn (Fig. 1B). Its phenotype was a reduced ability to cooperate with the proximal glucocorticoid-responsive element in the hormonal induction and also a reduction in the basal, unstimulated RNA level by a factor of 3 to 5 . Competition DNase I footprinting with the NF-I, octamer, or unspecific oligonucleotides was performed on this mutated DNA probe. Figure 7 shows that, in striking contrast to the wild-type situation, competition by the octamer sequence displaced efficiently the protein bound in the NF-I half-site. Competition by the NF-I sequence was also more efficient in displacing octamer-bound factors, as the footprint disappeared at a lower concentration of competitor (200-fold molar excess) than with the wild-type probe (500-fold molar excess). In summary, the data of Fig. 6 and 7 together suggest a nonreciprocal cooperation of NF-I in the binding of octamer-type factors on the wild-type MMTV DNA and a reciprocal stabilization of binding when only half of the NF-I palindromic recognition sequence is present.

\section{DISCUSSION}

In this study, the transcriptional role of octamer factor binding to a tandem motif present in front of the TATA box in the MMTV promoter was investigated. The use of stably transfected cells, containing relatively low levels of integrated plasmids, showed the importance of the copy number, affecting the ratio of factor to DNA template, for the functional outcome. Virus-infected cells contain only a few ( 1 to 20$)$ integrated proviruses $(26,43)$, and this situation is not necessarily comparable with that found in transiently transfected cells, in which DNA templates are present in large numbers (thousands per cell). Two mutagenesis studies of the MMTV octamer sites carried out with transientexpression assays in L cells (106) or HeLa cells (11) had shown an effect of octamer site mutations on the glucocorticoid response, to various extents; one study also showed an effect on base-level transcription (106). While the DNA sequences that replace the octamer sites differ and may influence the results, we also found a relatively small reduction of dexamethasone-stimulated RNA levels in transient assays monitored by quantitative S1 mapping. However, this was not the case when the mutants were analyzed under stable transfection conditions that allowed a separation of 
WT

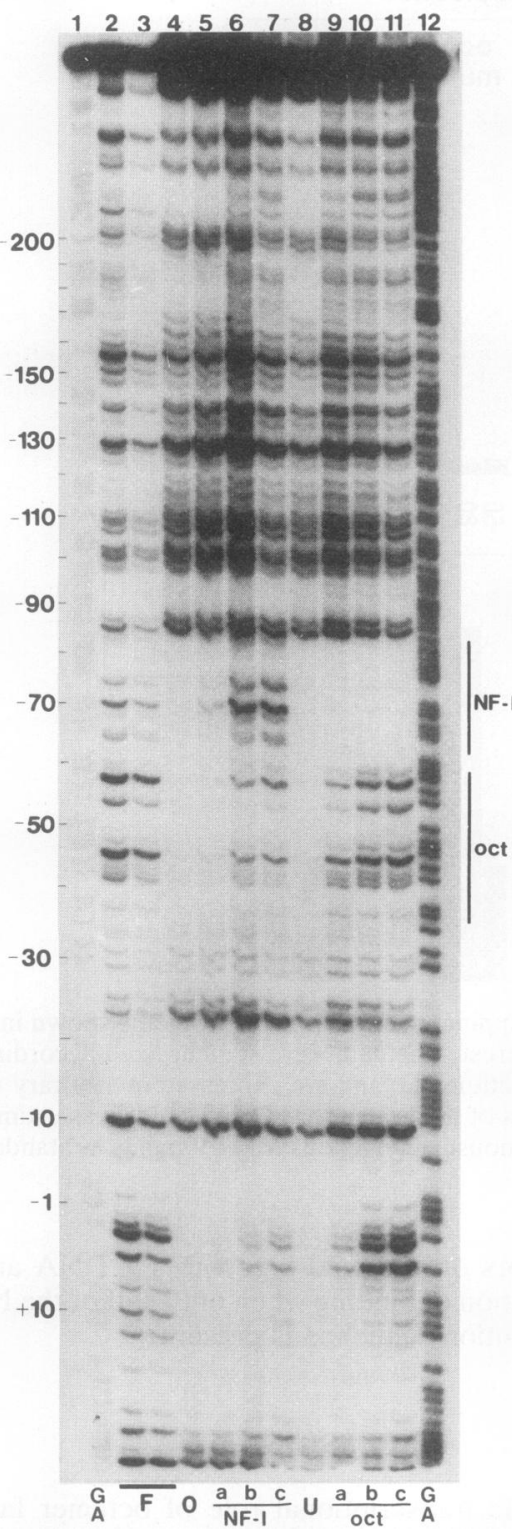

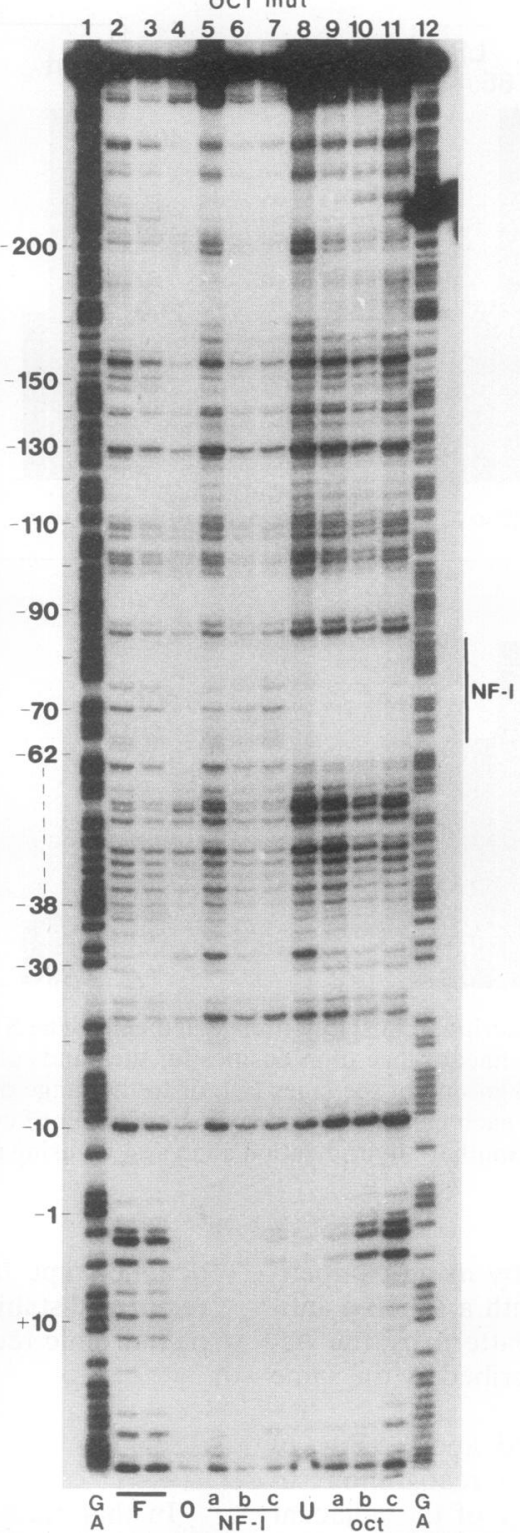

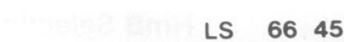

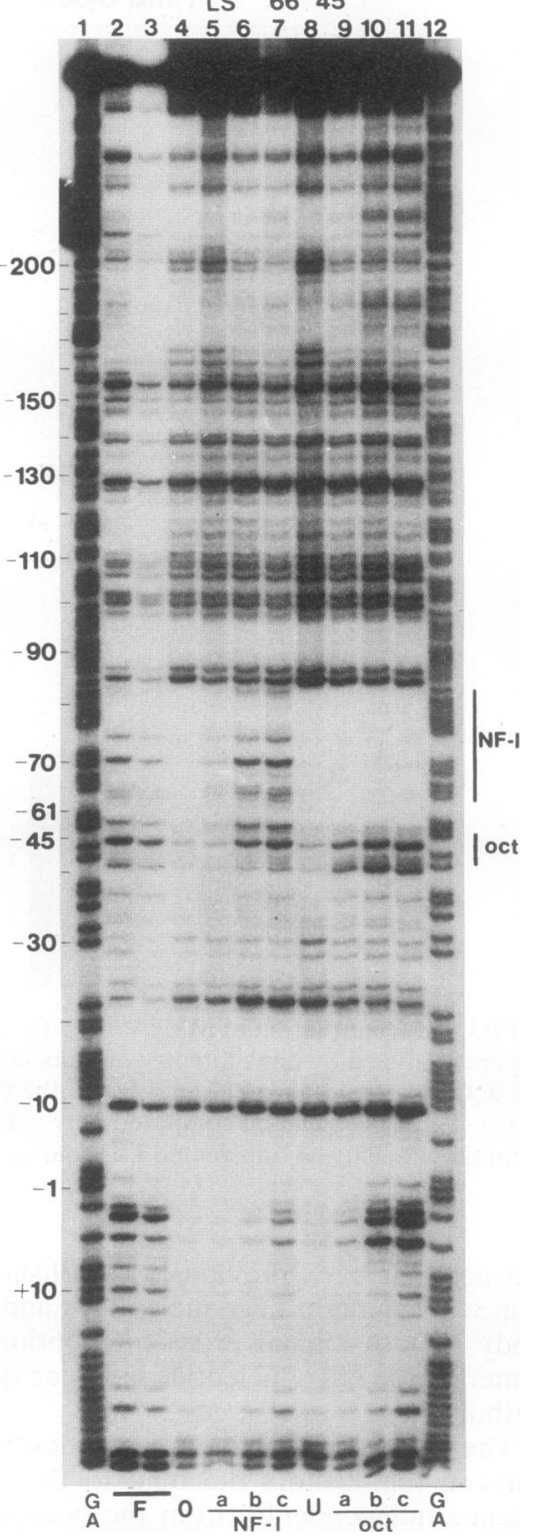

FIG. 6. DNase I footprinting analysis with wild-type or octamer-site mutant DNAs and competition experiments with oligonucleotides corresponding to the NF-I $(-83$ to -58$)$ or octamer $(-62$ to -39$)$ binding sites of MMTV DNA. DNA fragments $5^{\prime}$ end labeled at position +142 and extending to -303 were incubated with L-cell nuclear extract (lanes 4 to 11) or in its absence (lanes 2 and 3 , free DNA [F]) and subjected to DNase I digestion. In competition experiments (lanes 5 to 11), double-stranded oligonucleotides were preincubated with the extracts in molar excesses of 50-, 150-, and 450-fold, respectively, in lanes a (lanes 5 and 9), b (lanes 6 and 10), and c (lanes 7 and 11). The unspecific competitor (U, lane 8) from the adenovirus promoter was added at a 500-fold molar excess. No competitor was added in lane 4 . Lanes marked GA contain the purine sequencing reactions of the probes. Continuous vertical lines mark the positions of the relevant footprints, and a broken line marks that of the mutated sequences in the octamer mutant.

the effect on basal promoter activity from that on hormonally stimulated transcription.

Another important parameter for the interpretation of the functional studies is the relative affinity of DNA sites for transcription factors that was evaluated in the original sequence context by competition footprinting with nuclear protein extracts and wild-type or mutant DNA probes. I found that the binding affinity, together with the relative concentration of factors, may explain the transcriptional behavior of the MMTV promoter mutants, in a manner that is reminiscent of the regulation of immunoglobulin gene promoters by octamer factors (49). In MMTV, a further level of complexity is given by the peculiar arrangement of octamer and NF-I binding sites, similar to that observed for adenovirus type 2 , in which both are needed for initiation of DNA replication $(75,84,89)$ through simultaneous binding of NF-I and Oct-1 (84). The distance between the center of the NF-I palindrome and the first A of the octamer motif is $10 \mathrm{bp}$ in adenovirus type 2 and 14 bp in MMTV DNA.

The octamer sites are mainly involved in basal-level MMTV transcription. The data on stably transfected cells with the complete octamer site mutant showed that the mutation 

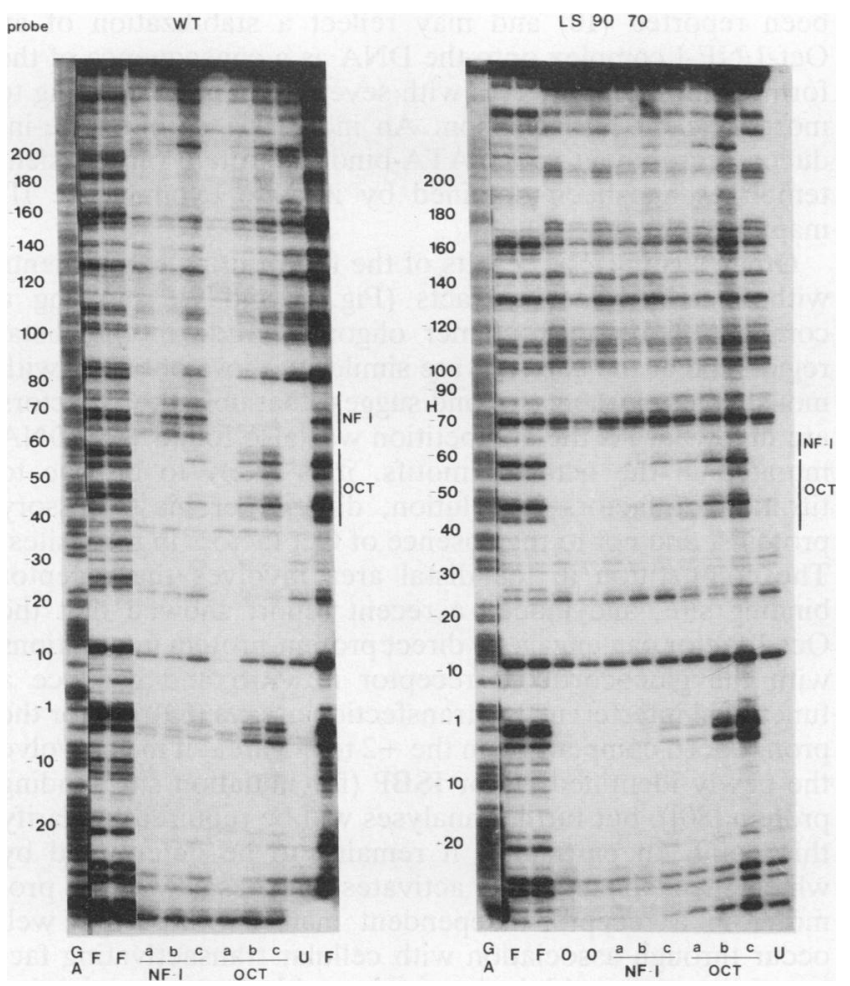

FIG. 7. DNase I footprinting analysis with wild-type DNA (WT) or mutant DNA with a deletion of half of the NF-I site (LS 90/70) and competition experiments with NF-I or octamer site oligonucleotides. The experimental conditions were those described in the legend to Fig. 6. The competitor oligonucleotides were used at mola excesses of 50-fold (lanes a), 200-fold (lanes b), and 500-fold (lanes c), and the unspecific competitor (U) was used at a 300 -fold excess.

affected the basal transcription level but not the dexamethasone-induced one. An explanation for the dichotomy of the single-site mutant with respect to base-level transcription (Fig. 5A and C) may be found in the combined effects of binding affinity and relative abundance of Oct factors. The oct oligonucleotide competition experiment (Fig. 6) showed that the binding affinity for the ubiquitous Oct-1 factor decreased from the wild-type sequence to the single-site mutant LS $-66 /-45$ to the double-site oct mutant. On the other hand, the relative ratio of factor to DNA decreases with increasing plasmid copy number. For the higher-affinity sites of the wild type, the available Oct factor is saturating, whereas for the extremely low-affinity sequence of the oct mutant the available factor is not sufficient even at the highest ratios, which are comparable to those in wild-type transfectants (Fig. 5A). The single-site LS mutant with an intermediate affinity is saturated at relatively low copy numbers (Fig. 5A) but not at high ones (Fig. 5C). It is also possible that in the TK selection procedure, the starting average transcriptional activity was lower than in the hygromycin B selection, such that only cells carrying a large number of plasmids (from the outset or through progressive amplification) were able to survive. A different organization of the chromatin containing multiple copies of plasmids, e.g., in the form of tandem repeats as previously observed (15), may also contribute to a lower specific activity per promoter unit present.

Earlier studies have shown that the basal level of transcription from the MMTV promoter is also negatively af- fected by mutations in the NF-I binding site both in transient assays (106) and in $\mathrm{Ltk}^{+}$stable transfectants $(16,52)$. The latter ones, produced in this laboratory in a way analogous to that of the present study, showed no increase in the number of integrated plasmids compared with wild-type transfectants. In one instance, in which an independent selection with hygromycin B was also used, this did not alter the relative differences in MMTV RNA levels between stimulated and unstimulated cultures or between mutants containing a complete or a half-NF-I binding site (52). These observations are consistent with the quantitative differences in the basal-level reductions, which were 50 - to 100 -fold in octamer site mutants and only 2- to 5-fold in NF-I mutants (in which the residual levels of TK mRNA were apparently sufficient to allow the survival of transfectants without a need for a higher number of templates). A tentative explanation for the effect of NF-I site mutations on the basal level may be found in the stabilizing function exerted by the occupied NF-I sequence on the binding of octamer factors to their site, which was observed with oligonucleotide competitions in footprinting experiments with nuclear extracts (Fig. 6 and 7). It is conceivable that a mutation of the NF-I site that reduces (Fig. 7) or abolishes NF-I binding would destabilize the interaction of Oct-1 with its sites, leading to a lowered base level of transcription. Mutual stabilization of DNA binding between Oct-1 and another protein (OAP ${ }^{40}$ ) recognizing a site $5^{\prime}$ to an octamer motif has been described for the antigen-inducible interleukin-2 enhancer (108).

The NF-I binding site is mainly involved in glucocorticoidstimulated MMTV transcription. The data from stably transfected cells also show that neither octamer mutant affected the hormone-induced levels (Fig. 4 and $5 B$ and D). In the hygromycin B-selected transfectants, the levels were higher than those of the control and seemed to reflect the number of DNA copies. In the DNase I footprints with nuclear extracts, the protection of the NF-I palindromic sequence was strong even in the octamer mutant DNA and was not affected by competition with octamer oligonucleotides (Fig. 6). This independence of NF-I binding seems to correlate with the unaltered dexamethasone response in $\mathrm{L}$ cells containing stably integrated octamer site mutant plasmids. Only in transient-expression assays did I observe a slight reduction (about 30\%) of dexamethasone-induced levels for the octamer mutant (Fig. 3), which may be explained by an indirect effect on NF-I binding in the following way. As shown by the oligonucleotide competition footprinting data of Fig. 7, in an unfavorable situation like the reduction of the recognition site to the half-palindrome (in LS -90/-70), the binding of NF-I was not autonomous as in the wild type but required the concomitant binding of Oct factor to the neighboring sites, possibly to help stabilize the weaker DNAprotein interactions. In the conditions of vast template excess of transiently transfected cells, even the wild-type NF-I site might need the octamer factor bound nearby. Its absence in oct mutant DNA might therefore destabilize NF-I binding and indirectly affect the dexamethasone-induced level of transcription. The role of NF-I in the glucocorticoid stimulation of MMTV expression has been established in several studies involving transfection of mutant promoters into various cell types $(11,15,16,19,41,68,106)$. Moreover, NF-I was shown to act as a hormone-dependent transcription factor when its cDNA was introduced into deficient JEG-3 choriocarcinoma cells, resulting in an increase of dexamethasone-stimulated RNA but not of the base level (12). Mutations in the MMTV NF-I site were shown to have a differential effect on the response to glucocorticoids versus 
progestins $(19,41)$. In cell-free transcription assays supplemented with glucocorticoid receptor, the NF-I binding site of MMTV showed a synergism with the glucocorticoid response element (2).

The results presented in this study demonstrate that effects on basal and induced transcription levels can be functionally separated and suggest a dependence on the concentration of factors and on the affinity of the corresponding DNA sites. One may predict that the asymmetry in the affinities of Oct-1 and NF-I for their respective DNA sequences in the MMTV promoter would be reflected in asymmetric responses to a lower concentration of one factor, depending on the cell type. A low amount of Oct-1 would bring about a low basal transcription level without affecting the maximal hormone inducibility, whereas a low amount of NF-I would give a reduction, but to a lesser extent, of both induced and basal levels. A large excess, or limiting amounts, of both factors would affect, positively or negatively, the base level more than the induced one. Therefore, it appears that the basal level of MMTV expression would be more subject to modulation by the availability of certain ubiquitous transcription factors, whereas the hormone-receptor complex would be the major determinant for a plateau of maximal transcriptional activity. These predictions can be tested in stable transfections with an independent selection.

Implications for the chromatin organization of MMTV DNA. The MMTV promoter was shown to be organized in nucleosomal structures in bovine papillomavirus-based episomes and in single integrated copies as well $(3,4,81,87)$. A phased array of nucleosomes is observed when the MMTV DNA is in a stable configuration within the cells but not when it is introduced in a transient fashion (4). Fine mapping has shown that the core of a nucleosome is positioned on the DNA segment spanning from -221 to -75 that includes both distal and proximal glucocorticoid response elements and the NF-I binding site at its $3^{\prime}$ edge. Another nucleosome is positioned on the TATA box and the beginning of the transcribed region, with its core between -23 and +123 , while the linker between these nucleosomes comprises the octamer motifs (10). The fundamentally different organization of stable versus transient chromatin was also shown by the observation that NF-I is constitutively present on transient templates but excluded from stable templates in the unstimulated state and only detectable upon glucocorticoid stimulation (4). It is believed that the binding of the hormone receptor (which can occur in the presence of the nucleosome core, contrary to NF-I) induces a structural transition of the chromatin that allows access of NF-I to it $(3,4,27)$. However, this fact could not explain the results of functional assays. Indeed, transcription from transient templates is also strongly hormone inducible, indicating that the receptor is the major determinant of the induction; on the other hand, a basal level of transcription is also observed with stable templates (in the absence of NF-I), making questionable its role in basal promoter function. The present results suggest such a role for the octamer-binding factor Oct-1. The inability to detect Oct-1 by in vivo footprinting assays (10) is likely due to its weak binding. The in vivo mapping assigned the octamer sites to the linker region between nucleosomes, where the presence of histone $\mathrm{H} 1$ was demonstrated by cross-linking and immunoadsorption studies (10). The affinity and concentration dependence of Oct-1 discussed above may then be exerted in competition with $\mathrm{H} 1$, as described for other transcription factors (55). A reduction in the amount of $\mathrm{H} 1$ per nucleosome upon dexamethasone activation has been reported (10) and may reflect a stabilization of an Oct-1/NF-I complex onto the DNA as a consequence of the formation of larger arrays with several receptors, leading to more efficient transcription. An indication of hormone-induced recruitment of a TATA-binding protein on transient templates has been obtained by in vivo exonuclease III mapping (4).

Other factors. The results of the footprinting experiments with L-cell nuclear extracts (Fig. 6 and 7), showing a competition by the octamer oligonucleotide in the distal region and at the cap site, are similar to those obtained with mouse liver extracts (65) and suggest that ubiquitous factors are involved. As the competition was also found with DNA mutated in the octamer motifs, it is likely to be due to titration of factors in solution, directly or via accessory proteins, and not to the absence of Oct factors in their sites. The competition in the distal area involves the receptor binding site, and indeed a recent report showed that the Oct-1 factor can engage in direct protein-protein interactions with the glucocorticoid receptor in vitro and produce a functional interference in transfection assays (53). As for the pronounced competition in the +2 to +5 area, it may involve the newly identified factor ISBP (for initiation site binding protein [80]), but further analyses will be required to clarify this point. In particular, it remains to be determined by which mechanism Oct-1 activates the basal MMTV promoter in a receptor-independent manner. This may well occur through association with cellular transactivating factors, by analogy with its interaction with the herpes simplex virus VP16 protein $(36,77,83,103)$. Finally, through the binding to the B-cell-specific Oct-2 factor, but possibly to the ubiquitous Oct-1 as well (49), the octamer sites may play a role in the transcription of MMTV in lymphocytes. These are among the first cells infected by the virus in mice (107), and they express a viral LTR-encoded protein with superantigen functions, leading to selective elimination of specific T-cell clones $(1,23,38)$.

\section{ACKNOWLEDGMENTS}

I thank Eric Kawashima (Glaxo) for the oligonucleotides used in this study, Béatrice Kunz for technical help, Heidi Diggelmann for her continued interest and support, and Peter Beard and Jovan Mirkovitch for critical reading of the manuscript.

This work was supported by the Swiss National Science Fund.

\section{REFERENCES}

1. Acha-Orbea, H., A. N. Shakhov, L. Scarpellino, E. Kolb, V. Müller, A. Vessaz-Shaw, R. Fuchs, K. Blöchlinger, P. Rollini, J. Billotte, M. Sarafidou, H. R. MacDonald, and H. Diggelmann. 1991. Clonal deletion of V- $\beta 14$-bearing T cells in mice transgenic for mammary tumor virus. Nature (London) 350:207211.

2. Allan, G. F., N. H. Ing, S. Y. Tsai, G. Srinivasan, N. L. Weigel, E. B. Thompson, M.-J. Tsai, and B. W. O'Malley. 1991. Synergism between steroid response and promoter elements during cell-free transcription. J. Biol. Chem. 266:5905-5010.

3. Archer, T. K., M. G. Cordingley, R. G. Wolford, and G. L. Hager. 1991. Transcription factor access is mediated by accurately positioned nucleosomes on the mouse mammary tumor virus promoter. Mol. Cell. Biol. 11:688-698.

4. Archer, T. K., P. Lefebvre, R. G. Wolford, and G. L. Hager. 1992. Transcription factor loading on the MMTV promoter: a bimodal mechanism for promoter activation. Science 255: 1573-1576.

5. Ball, J. K., H. Diggelmann, G. A. Dekaban, G. Grossi, R. Semmler, P. A. Waight, and R. F. Fletcher. 1988. Alterations in the $U 3$ region of the long terminal repeat of an infectious thymotropic type B retrovirus. J. Virol. 62:2985-2993. 
6. Banerji, J., L. Olson, and W. Schaffiner. 1983. A lymphocytespecific cellular enhancer is located downstream of the joining region in immunoglobulin heavy chain genes. Cell 33:724-740.

7. Banerji, J., S. Rusconi, and W. Schaffner. 1981. Expression of a $\beta$-globin gene is enhanced by remote SV40 DNA sequences. Cell 27:299-308.

8. Blochlinger, K., and H. Diggelmann. 1984. Hygromycin B phosphotransferase as a selectable marker for DNA transfer experiments with higher eucaryotic cells. Mol. Cell. Biol. 4:2929-2931.

9. Bohmann, D., W. Keller, T. Dale, H. R. Schöler, G. Tebb, and I. W. Mattaj. 1987. A transcription factor which binds to the enhancers of SV40, immunoglobulin heavy chain and U2 snRNA genes. Nature (London) 325:268-272.

10. Bresnick, E. H., C. Rories, and G. L. Hager. 1992. Evidence that nucleosomes on the mouse mammary tumor virus promoter adopt specific translational positions. Nucleic Acids Res. 20:865-870.

11. Brüggemeier, U., M. Kalff, S. Franke, C. Scheidereit, and M. Beato. 1991. Ubiquitous transcription factor OTF-1 mediates induction of the MMTV promoter through synergistic interaction with hormone receptors. Cell 64:565-572.

12. Brüggemeier, U., L. Rogge, E. L. Winnacker, and M. Beato. 1990. Nuclear factor I acts as a transcription factor on the MMTV promoter but competes with steroid hormone receptors for DNA binding. EMBO J. 9:2233-2239.

13. Buetti, E., and H. Diggelmann. 1981. Cloned mouse mammary tumor virus DNA is biologically active in transfected mouse cells and its expression is stimulated by glucocorticoid hormones. Cell 23:335-345.

14. Buetti, E., and H. Diggelmann. 1983. Glucocorticoid regulation of mouse mammary tumor virus: identification of a short essential DNA region. EMBO J. 2:1423-1429.

15. Buetti, E., and B. Kühnel. 1986. Distinct sequence elements involved in the glucocorticoid regulation of the mouse mammary tumor virus promoter identified by linker scanning mutagenesis. J. Mol. Biol. 190:379-389.

16. Buetti, E., B. Kühnel, and H. Diggelmann. 1989. Dual function of a nuclear factor 1 binding site in MMTV transcription regulation. Nucleic Acids Res. 17:3065-3078.

17. Cato, A. C. B., D. Henderson, and H. Ponta. 1987. The hormone response element of the mouse mammary tumor virus DNA mediates the progestin and androgen induction of transcription in the proviral long terminal repeat region. EMBO J. 6:363-368.

18. Cato, A. C. B., R. Miksicek, G. Schütz, J. Arnemann, and M. Beato. 1986. The hormone regulatory element of mouse mammary tumor virus mediates progesterone induction. EMBO J. 5:2237-2240.

19. Cato, A. C. B., P. Skroch, J. Weinmann, P. Butkeraitis, and H. Ponta. 1988. DNA sequences outside the receptor-binding sites differentially modulate the responsiveness of the mouse mammary tumour virus promoter to various steroid hormones. EMBO J. 7:1403-1410.

20. Chalepakis, G., J. Arnemann, E. Slater, H. J. Brüller, B. Gross, and M. Beato. 1988. Differential gene activation by glucocorticoids and progestins through the hormone regulatory element of mouse mammary tumor virus. Cell 53:371-382.

21. Chandler, V. L., B. A. Maler, and K. R. Yamamoto. 1983. DNA sequences bound specifically by glucocorticoid receptor in vitro render a heterologous promoter hormone responsive in vivo. Cell 33:489_499.

22. Chen, E. Y., and P. H. Seeburg. 1985. Supercoil sequencing: a fast and simple method for sequencing plasmid DNA. DNA 4:165-170.

23. Choi, Y., J. W. Kappler, and P. Marrack. 1991. A superantigen encoded in the open reading frame of the $3^{\prime}$ long terminal repeat of mouse mammary tumour virus. Nature (London) 350:203-207.

24. Chomczynski, P., and N. Sacchi. 1987. Single-step method of RNA isolation by acid guanidinium thiocyanate-phenol-chloroform extraction. Anal. Biochem. 162:156-159.

25. Ciliberto, G., R. Buckland, R. Cortese, and L. Philipson. 1985.
Transcription signals in embryonic Xenopus laevis U1 RNA genes. EMBO J. 4:1537-1543.

26. Cohen, J. C., P. R. Shank, V. L. Morris, R. Cardiff, and H. E. Varmus. 1979. Integration of the DNA of mouse mammary tumor virus-infected normal and neoplastic tissue of the mouse. Cell 16:333-345.

27. Cordingley, M. G., A. T. Riegel, and G. L. Hager. 1987. Steroid-dependent interaction of transcription factors with the inducible promoter of mouse mammary tumor virus in vivo. Cell 48:261-270.

28. Darbre, P., M. Page, and R. J. B. King. 1986. Androgen regulation by the long terminal repeat of mouse mammary tumor virus. Mol. Cell. Biol. 6:2847-2854.

29. Dudley, J. P., A. Arfsten, C. L. L. Hsu, C. Kozak, and R. Risser. 1986. Molecular cloning and characterization of mouse mammary tumor proviruses from a T-cell lymphoma. J. Virol. 57:385-388.

30. Falkner, F. G., and H. G. Zachau. 1984. Correct transcription of an immunoglobulin $\kappa$ gene requires an upstream fragment containing conserved sequence elements. Nature (London) 310:71-74.

31. Favaloro, J., R. Treisman, and R. Kamen. 1980. Transcription maps of polyoma virus-specific RNA: analysis by two-dimensional nuclease S1 gel mapping. Methods Enzymol. 65:718749.

32. Feinberg, A. P., and B. Vogelstein. 1983. A technique for radiolabeling DNA restriction endonuclease fragments to high specific activity. Anal. Biochem. 132:6-13.

33. Fletcher, C., N. Heintz, and R. G. Roeder. 1987. Purification and characterization of OTF-1, a transcription factor regulating cell cycle expression of a human histone $\mathrm{H} 2 \mathrm{~b}$ gene. Cell 51:773-781.

34. Galas, D., and A. Schmitz. 1978. DNase footprinting: a simple method for the detection of protein-DNA-binding specificity. Nucleic Acids Res. 5:3157-3170.

35. Gerster, T., P. Matthias, M. Thali, J. Jiricny, and W. Schaffiner. 1987. Cell type-specificity elements of the immunoglobulin heavy chain gene enhancer. EMBO J. 6:1323-1330.

36. Gerster, T., and R. G. Roeder. 1988. A herpesvirus transactivating protein interacts with transcription factor OTF-1 and other cellular proteins. Proc. Natl. Acad. Sci. USA 85:63476351.

37. Gillies, S. D., S. L. Morrison, V. T. Oi, and S. Tonegawa. 1983. A tissue-specific transcription enhancer element is located in the major intron of a rearranged immunoglobulin heavy chain gene. Cell 33:717-728.

38. Golovkina, T. V., A. Chervonsky, J. P. Dudley, and S. R. Ross. 1992. Transgenic mouse mammary tumor virus superantigen expression prevents viral infection. Cell 69:637-645.

39. Gorski, K., M. Carneiro, and U. Schibler. 1986. Tissue-specific in vitro transcription from the mouse albumin promoter. Cell 47:767-776.

40. Gouilleux, F., B. Sola, B. Couette, and H. Richard-Foy. 1991. Cooperation between structural elements in hormone-regulated transcription from the mouse mammary tumor virus promoter. Nucleic Acids Res. 19:1563-1569.

41. Gowland, P. L., and E. Buetti. 1989. Mutations in the hormone regulatory element of mouse mammary tumor virus differentially affect the response to progestins, androgens, and glucocorticoids. Mol. Cell. Biol. 9:3999-4008.

42. Graham, F. L., S. Bacchetti, R. McKinnon, C. Stanners, B. Cordell, and H. M. Goodman. 1980. Transformation of mammalian cells with DNA using the calcium technique, p. 3-25. In R. Baserga, C. Croce, and G. Rovera (ed.), Introduction of macromolecules into viable mammalian cells. Alan R. Liss, Inc., New York.

43. Groner, B., and N. E. Hynes. 1980. Number and location of mouse mammary tumor virus proviral DNA in mouse DNA of normal tissue and of mammary tumors. J. Virol. 33:1013-1025.

44. Günzburg, W. H., and B. Salmons. 1992. Factors controlling the expression of mouse mammary tumour virus. Biochem. J. 283:625-632.

45. Härtig, E., B. Nierlich, S. Mink, G. Nebl, and A. C. B. Cato. 
1993. Regulation of expression of mouse mammary tumor virus through sequences located in the hormone response element: involvement of cell-cell contact and a negative regulatory factor. J. Virol. 67:813-821.

46. He, X., M. N. Treacy, D. M. Simmons, H. A. Ingraham, L. W. Swanson, and M. G. Rosenfeld. 1989. Expression of a large family of POU-domain regulatory genes in mammalian brain development. Nature (London) 340:35-42.

47. Hsu, C.-L. L., C. Fabritius, and J. Dudley. 1988. Mouse mammary tumor virus proviruses in T-cell lymphomas lack a negative regulatory element in the long terminal repeat. $J$. Virol. 62:4644-4652.

48. Hynes, N., A. J. J. van Ooyen, N. Kennedy, P. Herrlich, H. Ponta, and B. Groner. 1983. Subfragments of the large terminal repeat cause glucocorticoid-responsive expression of mouse mammary tumor virus and of an adjacent gene. Proc. Natl. Acad. Sci. USA 80:3637-3641.

49. Kemler, I., E. Bucher, K. Seipel, M. M. Müller-Immerglück, and W. Schaffiner. 1991. Promoters with the octamer DNA motif (ATGCAAAT) can be ubiquitous or cell type-specific depending on binding affinity of the octamer site and Oct-factor concentration. Nucleic Acids Res. 19:237-242.

50. Kemler, I., and W. Schafiner. 1990. Octamer transcription factors and the cell type-specificity of immunoglobulin gene expression. FASEB J. 4:1444-1449.

51. Krol, A., E. Lund, and J. E. Dahlberg. 1985. The two embryonic U1 RNA genes of Xenopus laevis have both common and gene-specific transcription signals. EMBO J. 4:1529-1535.

52. Kühnel, B., E. Buetti, and H. Diggelmann. 1986. Functional analysis of the glucocorticoid regulatory elements present in the mouse mammary tumor virus long terminal repeat. A synthetic distal binding site can replace the proximal binding domain. J. Mol. Biol. 190:367-378.

53. Kutoh, E., P.-E. Strömstedt, and L. Poellinger. 1992. Functional interference between the ubiquitous and constitutive octamer transcription factor 1 (OTF-1) and the glucocorticoid receptor by direct protein-protein interaction involving the homeo subdomain of OTF-1. Mol. Cell. Biol. 12:4960-4969.

54. Landolfi, N. F., J. D. Capra, and P. W. Tucker. 1986. Interaction of cell-type-specific nuclear proteins with immunoglobulin $\mathrm{V}_{\mathrm{H}}$ promoter region sequences. Nature (London) 323:548-551.

55. Laybourn, P. J., and J. T. Kadonaga. 1991. Role of nucleosomal cores and histone $\mathrm{H} 1$ in regulation of transcription by RNA polymerase II. Science 254:238-244.

56. Lee, W. T., O. Prakash, D. Klein, and N. H. Sarkar. 1987. Structural alterations in the long terminal repeat of an acquired mouse mammary tumor virus provirus in a T-cell leukemia of DBA/2 mice. Virology 159:39-48.

57. Lefebvre, P., D. S. Berard, M. G. Cordingley, and G. L. Hager. 1991. Two regions of the mouse mammary tumor virus long terminal repeat regulate the activity of its promoter in mammary cell lines. Mol. Cell. Biol. 11:2529-2537.

58. Lichtsteiner, S., J. Wuarin, and U. Schibler. 1987. The interplay of DNA-binding proteins on the promoter of the mouse albumin gene. Cell 51:963-973.

59. Littlefield, J. W. 1964. Selection of hybrids from mating of fibroblasts in vitro and their presumed recombinants. Science 145:709-710.

60. Lopata, M. A., D. W. Cleveland, and B. Sollner-Webb. 1984. High level transient expression of a chloramphenicol acetyl transferase gene by DEAE-dextran mediated DNA transfection coupled with a dimethyl sulfoxide or glycerol shock treatment. Nucleic Acids Res. 12:5707-5717.

61. Majors, J. E., and H. E. Varmus. 1983. A small region of the mouse mammary tumor virus long terminal repeat confers glucocorticoid hormone regulation on a linked heterologous gene. Proc. Natl. Acad. Sci. USA 80:5866-5870.

62. Mantei, N., W. Boll, and C. Weissmann. 1979. Rabbit $\beta$-globin mRNA production in mouse $L$ cells transformed with cloned rabbit $\beta$-globin chromosomal DNA. Nature (London) 281:4046.

63. Mattaj, I. W., S. Lienhard, J. Jiricny, and E. M. De Robertis. 1985. An enhancer-like sequence within the Xenopus U2 gene promoter facilitates the formation of stable transcription complexes. Nature (London) 316:163-167.

64. Maxam, A. M., and W. Gilbert. 1980. Sequencing end-labeled DNA with base specific chemical cleavages. Methods Enzymol. 65:499-560.

65. Meulia, T., and H. Diggelmann. 1990. Tissue specific factors and glucocorticoid receptors present in nuclear extracts bind next to each other in the promoter region of mouse mammary tumor virus. J. Mol. Biol. 216:859-872.

66. Michalides, R., and E. Wagenaar. 1986. Site-specific rearrangements in the long terminal repeat of extra mouse mammary tumor proviruses in murine $T$-cell leukemias. Virology 154:7684.

67. Michalides, R. E., E. Wagenaar, and P. Weijers. 1985. Rearrangements in the long terminal repeat of extra mouse mammary tumor provirus in $T$ cell leukemias of mouse strain GR results in a novel enhancer-like structure. Mol. Cell. Biol. 5:823-830.

68. Miksicek, R., U. Borgmeyer, and J. Nowock. 1987. Interaction of the TGGCA-binding protein with upstream sequences is required for efficient transcription of mouse mammary tumor virus. EMBO J. 6:1355-1360.

69. Mink, S., E. Härtig, P. Jennewein, W. Doppler, and A. C. B. Cato. 1992. A mammary cell-specific enhancer in mouse mammary tumor virus DNA is composed of multiple regulatory elements including binding sites for CTF/NF1 and a novel transcription factor, mammary cell-activating factor. Mol. Cell. Biol. 12:4906-4918.

70. Mink, S., H. Ponta, and A. C. B. Cato. 1990. The long terminal repeat region of the mouse mammary tumour virus contains multiple regulatory elements. Nucleic Acids Res. 18:20172024.

71. Minty, A. J., S. Alonso, J. L. Guénet, and M. E. Buckingham. 1983. Number and organization of actin-related sequences in the mouse genome. J. Mol. Biol. 167:77-101.

72. Mok, E., T. V. Golovkina, and S. R. Ross. 1992. A mouse mammary tumor virus mammary gland enhancer confers tissue-specific but not lactation-dependent expression in transgenic mice. J. Virol. 66:7529-7532.

73. Morley, K., M. G. Toohey, and D. O. Peterson. 1987. Transcriptional repression of a hormone-responsive promoter. $\mathrm{Nu}$ cleic Acids Res. 15:6973-6989.

74. Mosthaf, L., M. Pawlita, and P. Gruss. 1985. A viral enhancer element specifically active in human haematopoietic cells. Nature (London) 315:597-600.

75. Nagata, K., R. A. Guggenheimer, T. Enomoto, J. H. Lichy, and J. Hurwitz. 1982. Adenovirus DNA replication in vitro: identification of a host factor that stimulates synthesis of the preterminal protein-dCMP complex. Proc. Natl. Acad. Sci. USA 79:6438-6442.

76. Nowock, J., U. Borgmeyer, A. W. Püschel, R. A. W. Rupp, and A. E. Sippel. 1985. The TGGCA protein binds to the MMTVLTR, the adenovirus origin of replication and the BK virus enhancer. Nucleic Acids Res. 13:2045-2061.

77. O'Hare, P., and C. R. Goding. 1988. Herpes simplex virus regulatory elements and the immunoglobulin octamer domain bind a common factor and are both targets for virion transactivation. Cell 52:435-445.

78. Okamoto, K., H. Okazawa, A. Okuda, M. Sakai, M. Muramatsu, and H. Hamada. 1990. A novel octamer binding transcription factor is differentially expressed in mouse embryonic cells. Cell 60:461-472.

79. Parslow, T. G., D. L. Blair, W. J. Murphy, and D. K. Granner. 1984. Structure of the $5^{\prime}$ ends of immunoglobulin genes: a novel conserved sequence. Proc. Natl. Acad. Sci. USA 81: 2650-2654.

80. Pierce, J., B. E. Fee, M. G. Toohey, and D. O. Peterson. 1993. A mouse mammary tumor virus promoter element near the transcription initiation site. J. Virol. 67:415-424.

81. Piña, M., U. Brüggemeier, and M. Beato. 1990. Nucleosome positioning modulates accessibility of regulatory proteins to the mouse mammary tumor virus promoter. Cell 60:719-731.

82. Ponta, H., N. Kennedy, P. Skroch, N. E. Hynes, and B. Groner. 
1985. The hormonal response region in the mouse mammary tumor virus long terminal repeat can be dissociated from the proviral promoter and has enhancer properties. Proc. Natl. Acad. Sci. USA 82:1020-1024.

83. Preston, C. M., M. C. Frame, and M. E. M. Campbell. 1988. A complex formed between cell components and an HSV structural polypeptide binds to a viral immediate early gene regulatory DNA sequence. Cell 52:425-434.

84. Pruijn, G. J. M., W. Van Driel, and P. C. Van der Vliet. 1986 Nuclear factor III, a novel sequence-specific DNA-binding protein from HeLa cells stimulating adenovirus DNA replication. Nature (London) 322:656-659.

85. Pruijn, G. J. M., W. Van Driel, R. T. Van Miltenburg, and P. C. Van der Vliet. 1987. Promoter and enhancer elements containing a conserved sequence motif are recognized by nuclear factor III, a protein stimulating adenovirus DNA replication. EMBO J. 6:3771-3778.

86. Pruijn, G. J. M., R. T. Van Miltenburg, A. J. Claessens, and P. C. Van der Vliet. 1988. Interaction between the octamerbinding protein nuclear factor III and the adenovirus origin of DNA replication. J. Virol. 62:3092-3102.

87. Richard-Foy, H., and G. L. Hager. 1987. Sequence-specific positioning of nucleosomes over the steroid-inducible MMTV promoter. EMBO J. 6:2321-2328.

88. Rosales, R., M. Vigneron, M. Macchi, I. Davidson, J. H. Xiao, and P. Chambon. 1987. In vitro binding of cell-specific and ubiquitous nuclear proteins to the octamer motif of the SV40 enhancer and related motifs present in other promoters and enhancers. EMBO J. 6:3015-3025.

89. Rosenfeld, P. J., E. A. O'Neill, R. J. Wides, and T. J. Kelly. 1987. Sequence-specific interactions between cellular DNAbinding proteins and the adenovirus origin of DNA replication. Mol. Cell. Biol. 7:875-886.

90. Ross, S. R., C.-L. L. Hsu, Y. Choi, E. Mok, and J. P. Dudley. 1990. Negative regulation in correct tissue-specific expression of mouse mammary tumor virus in transgenic mice. Mol. Cell. Biol. 10:5822-5829.

91. Ruvkun, G., and M. Finney. 1991. Regulation of transcription and cell identity by POU domain proteins. Cell 64:475-478.

92. Sambrook, J., E. F. Fritsch, and T. Maniatis. 1989. Molecular cloning: a laboratory manual, 2nd ed. Cold Spring Harbor Laboratory Press, Cold Spring Harbor, N.Y.

93. Sanger, F., S. Nicklen, and A. R. Coulson. 1977. DNA sequencing with chain-terminating inhibitors. Proc. Natl. Acad. Sci. USA 74:5463-5467.

94. Sawadogo, M., and R. G. Roeder. 1985. Interaction of a gene-specific transcription factor with the adenovirus major late promoter upstream of the TATA box region. Cell 43:165175.

95. Scheidereit, C., and M. Beato. 1984. Contacts between hormone receptor and DNA double helix within a glucocorticoid regulatory element of mouse mammary tumor virus. Proc. Natl. Acad. Sci. USA 81:3029-3033.

96. Scheidereit, C., A. Heguy, and R. G. Roeder. 1987. Identification and purification of a human lymphoid-specific octamerbinding protein (OTF-2) that activates transcription of an immunoglobulin promoter in vitro. Cell 51:783-793.

97. Schöler, H. R., S. Ruppert, N. Suzuki, K. Chowdhuri, and P. Gruss. 1990. New type of POU domain in germ line-specific protein Oct-4. Nature (London) 344:435-439.

98. Shapiro, D. J., P. A. Sharp, W. W. Wahli, and M. J. Keller. 1988. A high-efficiency HeLa cell nuclear transcription extract. DNA 7:47-55.

99. Singh, H., R. Sen, D. Baltimore, and P. A. Sharp. 1986. A nuclear factor that binds to a conserved sequence motif in transcriptional control elements of immunoglobulin genes. Nature (London) 319:154-158.

100. Sive, H. L., N. Heintz, and R. G. Roeder. 1986. Multiple sequence elements are required for maximal in vitro transcription of a human histone H2B gene. Mol. Cell. Biol. 6:33293340.

101. Southern, E. M. 1975. Detection of specific sequences among DNA fragments separated by gel electrophoresis. J. Mol. Biol. 98:503-517.

102. Staudt, L. M., H. Singh, R. Sen, T. Wirth, P. A. Sharp, and D. Baltimore. 1986. A lymphoid-specific protein binding to the octamer motif of immunoglobulin genes. Nature (London) 323:640-643.

103. Stern, S., M. Tanaka, and W. Herr. 1989. The Oct-1 homoeodomain directs formation of a multiprotein-DNA complex with the HSV transactivator VP16. Nature (London) 341:624 630.

104. Sturm, R., T. Baumruker, B. R. Franza, and W. Herr. 1987. A 100-kD HeLa cell octamer binding protein (OBP100) interacts differently with two separate octamer-related sequences within the SV40 enhancer. Genes Dev. 1:1147-1160.

105. Theunissen, H. J. M., M. Paardekooper, L. J. Maduro, R. J. A. M. Michalides, and R. Nusse. 1989. Phorbol esterinducible T-cell-specific expression of variant mouse mammary tumor virus long terminal repeats. J. Virol. 63:3466-3471.

106. Toohey, M. G., J. W. Lee, M. Huang, and D. O. Peterson. 1990. Functional elements of the steroid hormone-responsive promoter of mouse mammary tumor virus. J. Virol. 64:4477-4488.

107. Tsubura, A., I. Muneo, S. Imai, A. Murakami, N. Oyaizu, R. Yasumizu, Y. Ohnishi, H. Tanaka, S. Morii, and S. Ikehara. 1988. Intervention of T-cells in transportation of mouse mammary tumor virus (milk factor) to mammary gland cells in vivo. Cancer Res. 48:6555-6559.

108. Ullman, K. S., W. M. Flanagan, C. A. Edwards, and G. R. Crabtree. 1991. Activation of early gene expression in T lymphocytes by Oct-1 and an inducible protein, $\mathrm{OAP}^{40}$. Science 254:558-562.

109. Wildeman, A. G., M. Zenke, C. Schatz, M. Wintzerith, T. Grundström, H. Matthes, K. Takahashi, and P. Chambon. 1986. Specific protein binding to the simian virus 40 enhancer in vitro. Mol. Cell. Biol. 6:2098-2105.

110. Yanagawa, S.-I., H. Tanaka, and A. Ishimoto. 1991. Identification of a novel mammary cell line-specific enhancer element in the long terminal repeat of mouse mammary tumor virus, which interacts with its hormone-responsive element. J. Virol. 65:526-531. 